\title{
The Carotenoids of Algae: Pigments from some Cryptomonads, a Heterokont and some Rhodophyceae
}

\author{
BY MARY BELLE ALLEN \\ Kaiser Foundation Research Institute, Richmond, California, U.S.A. \\ LISBETH FRIES \\ Institute of Physiological Botany, University of Uppsala, Sweden \\ T. W. GOODWIN AND D. M. THOMAS \\ Department of Agricultural Biochemistry, \\ University of Wales, Aberystwyth
}

(Received 8 July 1963)

\section{SUMMARY}

The carotenoids of two Cryptophytes, one heterokont and five Rhodophytes have been examined. The main pigments present are, in Cryptomonas sp., $\alpha$-carotene and diatoxanthin; in Hemiselmis virescens, $\alpha$-carotene, and diatoxanthin; in Vischeria sp., $\beta$-carotene and three unidentified xanthophylls; in Antithamnion plumula and Nemalion multifidum, $\beta$-carotene, lutein and neoxanthin; in Erythrotrichia carnea, Rhodosorus marinus and Polysiphonia fastigiata, $\beta$-carotene, zeaxanthin and lutein.

\section{INTRODUCTION}

The carotenoids of algae have always attracted biochemists because of their diversity as compared with those present in the leaves of higher plants (see Goodwin, 1952, 1961; Strain, 1958). During the past few years interest has been greatly stimulated because of the isolation for the first time of a number of unicellular algae in pure culture and because of the development of suitable media in which they could be cultivated in the laboratory on a comparatively large scale. Reports have appeared on the carotenoids of the Cryptomonad Cryptomonas ovata (Haxo \& Fork, 1959) and of a number of Chrysophyceae, Ochromonas danica and Prymnesium parvum (Allen, Goodwin \& Phagpolngarm, 1960), Isochrysis galbana (Dales, 1960; Jeffrey, 1961), Pseudopedinella sp., Phaeaster type Pavolva gyrans, Phaeocystis pouchetti, Chrysochromulina ericina, Dicracteria inomata and Hymenomonas sp. (Dales, 1960) and Sphaleromantis sp. (Jeffrey, 1961). Strain (1958) has described the pigments in a large number of Rhodophytes. The present paper reports our findings on two further Cryptomonads, Hemiselmis virescens and Cryptomonas sp., the heterokont Vischeria sp. and on several previously unexamined Rhodophytes: Nemalion multifidum, Antithamnion plumula, Erythrotrichia carnea, Rhodosorus marinus, and Polysiphonia fastigiata. 


\section{METHODS}

Cultivation. Cultures of Vischeria sp. were grown in the medium described in Table 1, at $18-20^{\circ}$ and illuminated by 'cool white' fluorescent tubes (175 f.c.). The Cryptomonads were grown under conditions described by Allen, Dougherty \& McLaughlin (1959). Three species of red algae (Nemalion multifidum, Antithamnion plumula and Erythrotrichia carnea) were collected on the west coast of Sweden and have since been cultivated in $100 \mathrm{ml}$. Pyrex flasks of an artificial sea water, ASP 6 (Provasoli, McLaughlin \& Droop, 1957). Diatoms and other small algae were removed by washing and careful manipulations under microscope, and by transfers

\section{Table 1. Medium for Vischeria sp.}

Peptone (Difco) (0.1\%) containing the macroelements and microelements indicated ( $2 \mathrm{ml}$. of micronutrient mix/l. medium).

\begin{tabular}{|c|c|c|c|}
\hline \multicolumn{2}{|c|}{ Macronutrients } & \multicolumn{2}{|c|}{ Micronutrients } \\
\hline \multicolumn{2}{|r|}{$\mathbf{M}$} & & mg./l. \\
\hline $\mathrm{NaNO}_{3}$ & 0.003 & $\mathrm{~B}\left(\mathrm{H}_{3} \mathrm{BO}_{3}\right)$ & $0 \cdot 5$ \\
\hline $\mathrm{CaCl}_{2}$ & 0.00022 & $\mathrm{Mn}\left(\mathrm{MnSO}_{4} \cdot \mathrm{H}_{2} \mathrm{O}\right)$ & 0.5 \\
\hline $\mathrm{MgSO}_{4}$ & $0 \cdot 00062$ & $\mathrm{Zn}\left(\mathrm{ZnSO}_{4} \cdot \mathbf{7} \mathrm{H}_{2} \mathrm{O}\right)$ & 0.005 \\
\hline $\mathrm{NaCl}$ & $0 \cdot 00043$ & $\mathrm{Cu}\left(\mathrm{CuSO}_{4} \cdot 5 \mathrm{H}_{2} \mathrm{O}\right)$ & 0.02 \\
\hline $\mathrm{K}_{2} \mathrm{HPO}_{4}$ & $0 \cdot 00044$ & $\mathrm{Mo}(\mathrm{MoO}) 85 \%$ & $0 \cdot 01$ \\
\hline $\mathrm{KH}_{2} \mathrm{PO}_{4}$ & $0 \cdot 0013$ & $\mathbf{V}\left(\mathrm{NH}_{4} \mathrm{VO}_{3}\right)$ & 0.01 \\
\hline & & Fe(NaFeEDTA)* & $4 \cdot 0$ \\
\hline
\end{tabular}

to new flasks. After repeated treatments with antibiotics and fungicides $N$. multifidum was obtained free from bacteria and yeasts (Fries, 1961). The cultures of A. plumula and $\boldsymbol{E}$. carnea, however, were not completely freed from bacterial or yeast contaminants. Nemalion multifidum was cultivated under a bank of five fluorescent tubes (Philips) consisting of two reflector-backed TL 55, one TL 5, and one TL 17. The light intensity was about 800 lux. The temperature was about $20^{\circ}$. Antithamnion plumula was cultivated at $10^{\circ}$ under the combined irradiation of an incandescent filament lamp, Luma $500 \mathrm{~W}$., and a mercury-vapour lamp, $265 \mathrm{~W}$., in a light intensity of 700 lux. Erythrotrichia carnea was cultivated under the conditions described by Fries (1960). After an incubation time of about 6 weeks the algae were removed from the flasks and freeze-dried immediately without washing. Rhodosorus marinus was obtained in axenic culture from Dr G. Giraud; it was collected at Banyuls (Giraud, 1958) and cultivated in artificial sea water ASP 6 at $20^{\circ} \mathrm{F}$. (Fries, 1960) and under the light conditions described above for N. multifidum.

Polysiphonia fastigiata was collected at Aberystwyth.

Extraction, separation and identification of pigments. Full details of our general procedures have already been reported (Allen et al. 1960). In addition thin-layer chromatography with the apparatus designed by Stahl (1962) was used in part of this work. 
RESULTS

\section{Carotenoid in Cryptomonads}

Cryptomonas sp. strain 35. The carotenoids were chromatographed on a mixture of $3+1(\mathrm{w} / \mathrm{w}) \mathrm{ZnCO}_{3}+$ celite and the column developed with light petroleum containing increasing concentrations of ether. Three main carotenoids were obtained (Table 2). Fraction 1 percolated through the column slowly with light petroleum as eluant, but ran through quickly with light petroleum containing $2 \%(\mathrm{v} / \mathrm{v})$ diethyl ether. It was purified on activated alumina (Grade $\mathbf{H}$ ) and exhibited the chromatographic and spectral properties of $\alpha$-carotene. This was confirmed by co-chromatography on $\mathrm{ZnCO}_{3}+$ celite $(3+1$ by wt.) with an authentic sample of $\alpha$-carotene prepared from carrots. No separation was obtained. No $\beta$-carotene was detected, although a very faint band, with an indeterminate absorption spectrum, closely followed $\alpha$-carotene on the column.

Table 2. The carotenoids present in Cryptomonas sp. strain 35

Pigment extract chromatographed on $\mathrm{ZnCO}_{3}$ celite $(3+1$, by wt.); fractions listed in order of increasing absorptive power.

\begin{tabular}{|c|c|c|c|c|c|}
\hline Fraction & Description & $\begin{array}{c}\text { Absorption } \\
\text { maxima }(\mathrm{m} \mu) \\
\text { in light } \\
\text { petroleum } \\
\left.\text { (b.p. } 60-\mathbf{8 0}^{\circ}\right)\end{array}$ & Identification & $\begin{array}{l}\text { Concn. } \\
\text { (mg./g. } \\
\text { dry wt.) }\end{array}$ & $\begin{array}{c}\% \text { of } \\
\text { total } \\
\text { pigment }\end{array}$ \\
\hline 1 & Yellow & $447 \cdot 5,477 \cdot 5$ & $\alpha$-Carotene & $0 \cdot 28$ & $13 \cdot 5$ \\
\hline 2 & Orange & $430 *, 451,482$ & Diatoxanthin & 1.08 & $73 \cdot 5$ \\
\hline \multirow[t]{2}{*}{3} & Pale yellow & 449,478 & Unknown & 0.25 & $13 \cdot 0$ \\
\hline & & & Total & $1 \cdot 61$ & - \\
\hline
\end{tabular}

Table 3. The carotenoids present in Hemiselmis virescens

Pigment extract chromatographed on $\mathrm{ZnCO}_{3}+$ celite $(3+1$, by wt. $)$; fractions listed in order of increasing absorptive power.

\begin{tabular}{|c|c|c|c|c|c|}
\hline Fraction & Description & $\begin{array}{c}\text { Absorption } \\
\text { maxima }(\mathbf{m} \mu) \\
\text { in light } \\
\text { petroleum } \\
\left.\text { (b.p. } 60-80^{\circ}\right)\end{array}$ & Identification & $\begin{array}{l}\text { Concn. } \\
\text { (mg./g. } \\
\text { dry wt.) }\end{array}$ & $\begin{array}{l}\% \text { of } \\
\text { total } \\
\text { pigment }\end{array}$ \\
\hline $\mathbf{1}$ & Yellow & $447 \cdot 5^{*}, 477 \cdot 5$ & $\alpha$-Carotene & 0.076 & $15 \cdot 9$ \\
\hline $\mathbf{2}$ & Yellow & $425,447 \cdot 5,477 \cdot 5$ & (?) & $0 \cdot 108$ & $\mathbf{2 2 \cdot 5}$ \\
\hline $\mathbf{3}$ & Yellow-orange & $430 *, 452,483$ & Diatoxanthin & $0 \cdot 160$ & $\mathbf{3 3 \cdot 0}$ \\
\hline \multirow[t]{2}{*}{4} & Bright red $\uparrow$ & $430 *, 450,480$ & Unknown & $0 \cdot 140$ & $28 \cdot 6$ \\
\hline & & & Total & $0 \cdot 484$ & 一 \\
\hline
\end{tabular}

Fraction 2 closely resembled diatoxanthin first described in diatoms by Strain, Manning \& Hardin (1944) and reported recently in Prymnesium parvum (Allen et al. 1960). The pigment most closely resembling diatoxanthin is zeaxanthin. Fraction 2 was, however, easily separated from an authentic specimen of zeaxanthin, 
prepared from yellow maize, on a $\mathrm{ZnCO}_{3}+$ celite column. Furthermore, the absorption maxima of samples obtained at different times were consistently slightly higher than those of zeaxanthin (448-449, $478 \mathrm{~m} \mu$, in light petroleum). Fraction 3 was very tightly absorbed on the $\mathrm{ZnCO}_{3}+$ celite column, and was eluted only with diethyl ether containing a trace of ethanol. It was not identified.

Hemiselmis virescens. The four pigments obtained from this organism (Droop's strain) are described in Table 3. Fraction 1 passed slowly through the column with light petroleum and was shown to be $\alpha$-carotene by co-chromatography with an authentic sample from carrots on $\mathrm{ZnCO}_{3}+$ celite $(1+1)$ and on activated alumina.

Fraction 2 had the spectral properties of lutein. That this was not lucein was demonstrated by co-chromatography on a $\mathrm{ZnCO}_{3}+$ celite column with an authentic sample of lutein isolated from grass; complete separation was obtained.

Fraction 3, the main fraction, resembled diatoxanthin in its properties; on cochromatography with the corresponding pigment from the Cryptomonas species examined in the previous experiment, no separation was obtained. Fraction 4, which formed a very tightly bound red zone at the top of the column, could only be eluted with ethanol. It was unidentified.

Table 4. The carotenoids present in Vischeria sp.

Pigment extracts chromatographed on $\mathrm{ZnCO}_{3}+$ celite $(3+1$, by wt. $)$; fractions listed in order of increasing absorptive power.

\begin{tabular}{|c|c|c|c|c|c|}
\hline Fraction & Description & $\begin{array}{c}\text { Absorption } \\
\text { maxima }(\mathrm{m} \mu) \\
\text { in light } \\
\text { petroleum } \\
\left.\text { (b.p. } 60-80^{\circ}\right)\end{array}$ & Identification & $\begin{array}{l}\text { Concn. } \\
\text { (mg./g. } \\
\text { dry wt.) }\end{array}$ & $\begin{array}{c}\% \text { of } \\
\text { total } \\
\text { pigment }\end{array}$ \\
\hline 1 & Yellow & $430 *, 451,480$ & $\beta$-Carotene & $\mathbf{3 \cdot 2 7}$ & $64 \cdot 1$ \\
\hline 2 & Pale yellow & Trace only & Unknown & Trace & - \\
\hline $\mathbf{3}$ & Orange-yellow & $422 \cdot 5,447,475$ & Unknown & $0 \cdot 86$ & $17 \cdot 0$ \\
\hline 4 & Bright yellow & 443,472 & Unknown & 0.56 & $11 \cdot 0$ \\
\hline \multirow[t]{2}{*}{$\mathbf{5}$} & Yellow & $425^{*}, 445,473$ & Unknown & $0 \cdot 32$ & $7 \cdot 9$ \\
\hline & & & Total & $5 \cdot 01$ & 一 \\
\hline
\end{tabular}

\section{Carotenoids in a heterokont}

Vischeria $s p$. Chromatographic separation of the carotenoids of Vischeria sp. yielded five components (Table 4). The first band was shown in the usual way to be $\beta$-carotene; no trace of $\alpha$-carotene could be observed. Fraction 2 is a small yellow band which appears to correspond to that observed in other heterokonts by Strain (1958), who states 'the two principal xanthophylls were often preceded by traces of another xanthophyll which formed a light yellow zone'. Fraction 3 was the main xanthophyll fraction; it was easily separated from lutein, which was less strongly absorbed, and was somewhat less strongly absorbed than diatoxanthin; it resembles the 'moderately sorbed xanthophyll' reported by Strain (1958). Fractions 4 and 5 also correspond to unknown xanthophylls reported by Strain. The very high relative concentration of $\beta$-carotene should be emphasized. 


\section{Carotenoids in Rhodophytes, subclass Florideae}

Nemalion multifidum. This alga, which belongs in the order Nemalionales, family Helminthocladiaceae, contained the pigments indicated in Table 5. Rechromatography of fraction 1 on alumina resulted in its separation into two zones; the major pigment was identified as $\beta$-carotene and the minor one as $\alpha$-carotene by co-chromatography with authentic samples. Fraction 3 was identified as lutein by comparison with an authentic sample from grass. The need to identify lutein unequivocally was important, because it has recently been shown that antheraxanthin (5,6-epoxyzeaxanthin), a pigment with an absorption spectrum almost identical with that of lutein, is the main xanthophyll of Euglena (Krinsky \& Goldsmith, 1960). Fraction 3, which could not be separated from authentic lutein on the

\section{Table 5. The carotenoids present in Nemalion multifidum}

Pigment extract chromatographed on $\mathrm{ZnCO}_{3}+$ celite $(3+1$, by wt.); fractions listed in order of increasing absorptive power.

\begin{tabular}{|c|c|c|c|}
\hline Fraction & Description & $\begin{array}{c}\text { Absorption } \\
\text { maxima }(\mathrm{m} \mu) \\
\text { in light } \\
\text { petroleum } \\
\left(\text { b.p. } 60-80^{\circ}\right)\end{array}$ & Identification \\
\hline 1 & Yellow & $425 *, 446,478$ & $\beta$-Carotene \\
\hline $\mathbf{2}$ & Pale yellow & $442 \cdot 5,443,472$ & Unknown \\
\hline 3 & Yellow-orange & $442 \cdot 5,446,475$ & Lutein \\
\hline 4 & Pale yellow & $420,438,468$ & Neoxanthin (probably) \\
\hline & \multicolumn{3}{|c|}{$\begin{array}{l}\alpha \text {-Carotene also present in small amounts. } \\
* \text { Inflexion. }\end{array}$} \\
\hline
\end{tabular}

Table 6. Quantitative distribution of carotenoids in Antithamnion plumula and Nemalion multifidum

\begin{tabular}{|c|c|c|c|c|}
\hline \multirow[b]{2}{*}{ Pigment } & \multicolumn{2}{|c|}{ A. plumula } & \multicolumn{2}{|c|}{ N. multifidum } \\
\hline & $\begin{array}{c}\text { mg./g. } \\
\text { (dry wt.) }\end{array}$ & $\begin{array}{l}\% \text { of total } \\
\text { pigment }\end{array}$ & $\begin{array}{l}\text { mg./g. } \\
\text { (dry wt.) }\end{array}$ & $\begin{array}{l}\% \text { of total } \\
\text { pigment }\end{array}$ \\
\hline$\alpha$-Carotene & Traces & - & $0 \cdot 014$ & $1 \cdot 7$ \\
\hline$\beta$-Carotene & $0 \cdot 108$ & $14 \cdot 9$ & $0 \cdot 103$ & $12 \cdot 6$ \\
\hline Unknown & $0 \cdot 042$ & $5 \cdot 8$ & $0 \cdot 050$ & $6 \cdot 1$ \\
\hline Lutein & $0 \cdot 0480$ & $66 \cdot 5$ & 0.400 & $49 \cdot 0$ \\
\hline Neoxanthin? & 0.092 & $12 \cdot 8$ & 0.050 & $30 \cdot 6$ \\
\hline Total & $0 \cdot 722$ & - & $0 \cdot 617$ & - \\
\hline
\end{tabular}

$\mathrm{ZnCO}_{3}+$ celite column, was therefore mixed with authentic antheraxanthin prepared from Euglena gracilis; the two pigments were easily separated on a $\mathrm{ZnCO}_{3}+$ celite column. Confirmation was obtained by running a thin-layer chromatogram of the various pigments on a silicic acid + rice starch plate with a mixture of ethyl acetate + light petroleum $(35+65$, by vol.) as developer. Fraction 3 was not separated from lutein, but was separated from antheraxanthin. Fraction 4 closely resembled neoxanthin and was not separated completely from an authentic specimen of neoxanthin, although very slight separation appeared to take place in occasional 
samples. We concluded that fraction 4 was probably neoxanthin, but cannot state this categorically. Fraction 2 occurred only in traces and was not identified.

Antithamnion plumula. The pigments in this alga, which belongs in the order Ceramiales, family Ceramiaceae, are the same as those found in Nemalion multifidum and will not be described in detail. They do, however, differ quantitatively as indicated in Table 6.

Polysiphonia fastigiata. The pigments in this alga, a member of the order Ceramiales, family Rhodomelaceae, were a comparatively simple mixture of $\beta$ carotene, zeaxanthin and lutein (Table 7); these were identified by comparison with authentic pigments. It is significant that zeaxanthin predominates over lutein.

Table 7. The carotenoids present in Polysiphonia fastigiata

Pigment extract chromatographed on $\mathrm{ZnCO}_{3}+$ celite; fractions listed in order of increasing absorptive power.

\begin{tabular}{|c|c|c|c|c|c|}
\hline Fraction & Description & $\begin{array}{l}\text { Absorption } \\
\text { maxima }(\mathrm{m} \mu) \\
\text { in light } \\
\text { petroleum } \\
\left(\text { b.p. } 60-80^{\circ}\right)\end{array}$ & Identification & $\begin{array}{l}\text { Conen. } \\
\text { (mg./g. } \\
\text { dry wt.) }\end{array}$ & $\begin{array}{c}\% \text { of } \\
\text { total } \\
\text { pigment }\end{array}$ \\
\hline 1 & Yellow & $430^{*}, 452,481$ & $\beta$-Carotene & $0 \cdot 024$ & $27 \cdot 3$ \\
\hline 2 & Orange-yellow & $430 *, 451,480$ & Zeaxanthin & $0 \cdot 040$ & $55 \cdot 4$ \\
\hline \multirow[t]{2}{*}{3} & Yellow & $423,445,472.5$ & Lutein & 0.024 & $27 \cdot 3$ \\
\hline & & & Total & 0.088 & 一 \\
\hline
\end{tabular}

Table 8. The carotenoids present in Erythrotrichium carnea

Pigment extract chromatographed on $\mathrm{ZnCO}_{3}+$ celite $(3+1$, by wt.); fractions listed in order of increasing absorptive power.

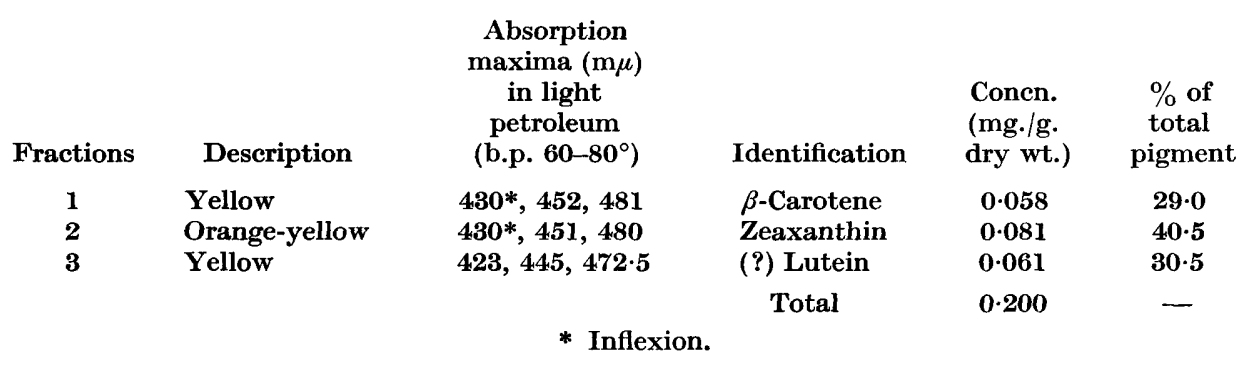

Carotenoids in Rhodophytes, subclass Bangioideae

Erythrotrichia carnea. Only one very small sample (49 mg./dry wt.) of this alga, which belongs to the order Bangiales, was available. Considerable difficulty was encountered in extracting the carotenoids; they were released slowly with absolute methanol; no extraction occurred with acetone or absolute ethanol. A comparatively low concentration of pigment was present $(0 \cdot 2 \mathrm{mg}$./g. dry wt. compared with, for example, $0.8 \mathrm{mg} . / \mathrm{g}$. in Nemalion multifidum). All the separations reported here were done on $40 \mu \mathrm{g}$. of pigment. A small column was used $(15 \times 0.8 \mathrm{~cm}$. $)$ and the absorption spectra were measured in microcells containing $0.3 \mathrm{ml}$. instead of 3-4 $\mathrm{ml}$. of solution; the separation obtained is recorded in Table 8. Fractions 1, 
and 2 were clearly identified by co-chromatography with authentic samples of $\beta$-carotene and zeaxanthin, respectively. As far as could be judged with the small amounts available, no $\alpha$-carotene was present. Fraction 3 was similar in adsorptive power to lutein, but its absorption maxima were at slightly lower wavelengths. Unfortunately, it was not possible to carry out a mixed chromatogram with authentic lutein, but we feel that $\mathrm{C}$ is probably lutein which had been isomerized during experimental manipulation.

Rhodosorus marinus. The pigment separation obtained with this alga, a member of the order Porphyridiales, is given in Table 9. By the usual criteria Fractions 1, 2 and 3 were identified as $\beta$-carotene, zeaxanthin and lutein, respectively. There was no indication of the presence of $\alpha$-carotene and there is more than ten times more zeaxanthin present than lutein.

Table 9. The carotenoids present in Rhodosorus marinus

Pigment extract chromatographed on $\mathrm{ZnCO}_{3}+$ celite $(3+1$, by wt.); fractions listed in order of increasing absorptive power.

\begin{tabular}{|c|c|c|c|c|c|}
\hline Fractions & Description & $\begin{array}{c}\text { Absorption } \\
\text { maxima }(\mathrm{m} \mu) \\
\text { in light } \\
\text { petroleum } \\
\left.\text { (b.p. } 60-80^{\circ}\right)\end{array}$ & Identification & $\begin{array}{l}\text { Concn. } \\
\text { (mg./g. } \\
\text { dry wt.) }\end{array}$ & $\begin{array}{c}\% \text { of } \\
\text { total } \\
\text { pigment }\end{array}$ \\
\hline 1 & Yellow & $430 *, 452,480$ & $\beta$-Carotene & $0 \cdot 086$ & $21 \cdot 0$ \\
\hline 2 & Orange-yellow & $430 *, 452,481$ & Zeaxanthin & 0.291 & $70 \cdot 9$ \\
\hline \multirow[t]{2}{*}{3} & Yellow-orange & $427 \cdot 5,447 \cdot 5,477 \cdot 5$ & Lutein & 0.024 & $8 \cdot 1$ \\
\hline & & & Total & 0.401 & - \\
\hline
\end{tabular}

\section{DISCUSSION}

Cryptomonads. The Cryptomonas sp. which was examined in this work is very similar to Cryptomonas ovata examined by Haxo \& Fork (1959). In both cases, the major carotene is $\alpha$-carotene, with no $\beta$-carotene. The major xanthophyll is diatoxanthin in Cryptomonas sp. and in $C$. ovata 'the principal xanthophyll corresponded closely to zeaxanthin; however, identity with diatoxanthin was not precluded' (Haxo \& Fork, 1959). Furthermore, the xanthophyll pigments preponderate in both species, the ratio xanthophylls to carotenes being 6*4:1 and $2 \cdot 4: 1$ for Cryptomonas sp. and $C$. ovata, respectively. In neither species was lutein, fucoxanthin or peridinin observed. The situation in Hemiselmis virescens is very similar; diatoxanthin is the main xanthophyll, and $\alpha$-carotene is the main carotene; $\beta$-carotene could not be detected.

Heterokonts (Xanthophyceae). Strain (1958) studied a number of heterokonts including Vischeria stellata. The present results on our Vischeria sp. are in general agreement with his in that $\beta$-carotene is the main carotene present and three or four unidentified pigments are present in the xanthophyll fraction. Lutein was not identified in any specimen. This compares with the observation of Jamikorn (1954) that lutein was present in Tribonema aequale, Heterococcus fuoreresis, and Ophiocytium majus. A unique feature of our strain of Vischeria sp. is that $\beta$-carotene predominates over the xanthophylls. 
The Rhodophytes. To facilitate more detailed discussion of the red algae the general classification of the Bangioideae and Florideae is given in Table 10. Rhodosorus marinus (order Porphyridiales) is like another member of the same order, Porphyridium cruentum studied by Strain (1958) in synthesizing zeaxanthin and lutein but not $\alpha$-carotene. Erythrotrichia carnea, a member of another order, Bangiales, in the subclass Bangioideae, qualitatively resembles $R$. marinus; the two algae differ quantitatively, however, in that the amount of zeaxanthin relative to that of lutein is very much greater in $R$. marinus $(9: 1)$ than in $E$. carnea $(1 \cdot 3: 1)$. Erythrotrichia carnea is generally similar to the two Bangiales, Porphyra naiadum and $\boldsymbol{P}$. perforata, studied by Strain (1958) in synthesizing zeaxanthin and lutein; however, $\boldsymbol{P}$. perforata also synthesized $\alpha$-carotene, which was not observed in E. carnea or P. naiadum.

\title{
Table 10. The general classification of the Bangioideae and Florideae (Rhodophyta)
}

\author{
Subclass I, Bangioideae \\ Order 1, Porphyridiales \\ Rhodosorus \\ Porphyridium \\ Order 2, Goniotrichales \\ Goniotrichum \\ Order 3, Bangiales \\ Erythrotrichia \\ Porphyra \\ Subclass II, Florideae \\ Order Nemalionales \\ Fam. Chantransiaceae (Rhodochorton) \\ Fam. Helminthocladiaceae (Nemalion, Cumagloea) \\ Fam. Chaetangiaceae (Gloiphloea, Galaxaura) \\ Order Ceramiales \\ Fam. Ceramiaceae (Antithamnion) \\ Fam. Rhodomelaceae (Polysiphonia)
}

Nemalion multifidum (order Nemalionales, family Helminthocladiaceae) differs from Cumagloea andersonii and Galaxaura sp. (same family; Strain, 1958) in that it does not synthesize zeaxanthin. Furthermore, $N$. multifidum synthesizes a pigment similar to neoxanthin; Strain (1958) never reported neoxanthin in any of a large number of Rhodophytes which he examined. Polysiphonia fastigiata (order Nemalionales, family Rhodomelaceae) is very similar to three other Polysiphonia species examined by Strain (1958), viz. P. aquamara, $\boldsymbol{P}$. californica and $\boldsymbol{P}$. collinsii. In all cases $\alpha$-carotene was not detected and zeaxanthin preponderated over lutein; indeed rather surprisingly, no lutein was found by Strain in $P$. collinsii.

The observations recorded here on five Rhodophytes which had not previously been examined confirm the general conclusion of Strain (1958), who examined a very large number of red algae, that the main qualitative variations in the carotenoid pigment systems of the Rhodophytes, irrespective of the order to which they belong, are the presence or absence of zeaxanthin and the presence or absence of $\alpha$-carotene. The further demonstration of the existence of $\alpha$-carotene and $\beta$-carotene derivatives together in Rhodophytes adds weight to the conclusion that on evidence from caro- 
tenoid studies the Rhodophytes occupy a central position in the evolutionary pattern of the algae (Goodwin, 1962).

The participation of M. B. A. in this investigation was partly supported by the National Science Foundation, U.S.A. (Grant G-13181).

\section{REFERENCES}

Aluen, M. B., Dougherty, E. C. \& Mclaughuin, J. J. A. (1959). Chromoprotein pigments of some cryptomonad flagellates. Nature, Lond. 184, 1047.

Alien, M. B., Goodwin, T. W. \& Phagpolngarm, S. (1960). Carotenoid distribution in certain naturally occurring algae and in some artificially induced mutants of Chlorella pyrenoidosa. J. gen. Microbiol. 23, 93.

DaLES, R. P. (1960). On the pigments of the Crysophyceae. J. mar. biol. Ass. U.K. 39, 693.

FrIes, L. (1960). The influence of different $\mathrm{B}_{12}$ analogues on the growth of Goniotrichum elegans (Chauv.). Physiol. Plant. 13, 264.

FrIES, L. (1961). Vitamin requirements of Nemalion multifidum. Experientia, 17, 75.

GrRaUd, G. (1958). Sur la vitesse de croissance d'une Rhodophycée monocellulaire marine, le Rhodosorus marinus Geilter, cultivée en milieu synthetique. C.r. Séanc. Soc. Biol. 246, 3501.

Goodwin, T. W. (1952). The Comparative Biochemistry of the Carotenoids. London: Chapman and Hall.

Goodwin, T. W. (1961). Comparative Biochemistry of Carotenoids. Proc. Symp. III. 5th Int. Congr. Biochem. 3, 300.

Goodwin, T. W. (1962). Carotenoids : structure, distribution and function. In Comparative Biochemistry, 4, 643. Ed. by M. Florkin \& H. S. Mason. New York: Academic Press.

HAXo, F. T. \& Fork, D. C. (1959). Photosynthetically active accessory pigments of cryptomonads. Nature, Lond. 184, 1061.

JAMIKORN, M. (1954). Carotenogenesis in Mycobacterium phlei and other microorganisms. Ph.D. Thesis. University of Liverpool.

Jefrrey, S. W. (1961). Paper chromatographic separation of chlorophylls and carotenoids from marine algae. Biochem. J. 80, 336.

Krinsky, N. I. \& Goldsmith, T. H. (1960). The carotenoids of the flagellated alga, Euglena gracilis. Archs. Biochem. 91, 271.

Provasoli, L., McLaughlin, J. J. A. \& Droop, M. R. (1957). The development of artificial media for marine algae. Archs. Mikrobiol. 25, 392.

Stahl, E. (1962). Dü̈nschicht Chromatographie. Heidelberg: Springer.

Strain, H. H. (1958). Chloroplast Pigments and Chromatographic Analysis. Pennsylvania State University Press.

Strain, H. H., Manning, W. M. \& Hardin, G. (1944). Xanthophylls and carotenes of diatoms, brown algae, dinoflagellates and sea anemones. Biol. Bull. mar. biol. Lab., Woods Hole, 86, 170. 